\title{
Adult-onset Still's disease with macrophage activation syndrome diagnosed and treated based on cytokine profiling: a case-based review
}

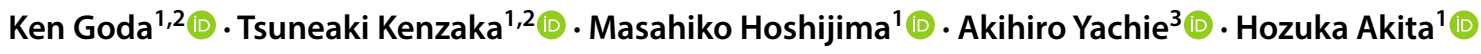

Received: 16 July 2019 / Accepted: 12 September 2019 / Published online: 20 September 2019

(c) The Author(s) 2019

\begin{abstract}
Adult-onset Still's disease (AOSD) is a relatively rare systemic inflammatory disorder and is diagnosed using various sets of classification criteria, with the Yamaguchi criteria as the most widely used criteria. Herein, we present the case of a 21-yearold woman admitted with a high fever, lasting for over 1 month, who did not fulfill the Yamaguchi criteria. However, by analyzing the inflammatory cytokine profile, we defined this case as AOSD based on a greatly elevated serum interleukin-18 level. In addition, we predicted the occurrence of macrophage activation syndrome by a characteristic increase in the soluble tumor necrosis factor receptor II level, which allowed a timely intervention for this malicious complication. Therefore, we suggest that cytokine profiling will be useful for the diagnosis and management of AOSD.
\end{abstract}

Keywords Adult-onset still's disease $\cdot$ Cytokines $\cdot$ Macrophage activation syndrome $\cdot$ Diagnosis

\section{Introduction}

AOSD is a rare systemic inflammatory disorder characterized by a high spiking fever, an evanescent salmon-pink rash, and arthritis, frequently accompanied by a sore throat, myalgias, lymphadenopathies, splenomegaly, and neutrophilic leukocytosis. The etiology is still unknown; however,

Tsuneaki Kenzaka

smile.kenzaka@jichi.ac.jp

Ken Goda

kenkenpetneed@yahoo.co.jp

Masahiko Hoshijima

mhoshijima@gmail.com

Akihiro Yachie

yachie@staff.kanazawa-u.ac.jp

Hozuka Akita

hozuka_Akita@pref.hyopgo.lg.jp

1 Department of Internal Medicine, Hyogo Prefectural Tamba Medical Center, 2002-7 Iso, Hikami-cho, Tamba 669-3495, Japan

2 Division of Community Medicine and Career Development, Kobe University Graduate School of Medicine, 2-1-5 Arata-cho, Hyogo-ku, Kobe 652-0032, Japan

3 Department of Pediatrics, Kanazawa University, 13-1, Takaramachi, Kanazawa 920-8641, Japan an important role is played by various infectious agents, which act as triggers in genetically predisposed hosts [1]. Furthermore, AOSD is considered the adult counterpart of systemic juvenile idiopathic arthritis (s-JIA); several phenotypic characteristics are shared, including daily recurring fevers, a salmon-colored skin rash, and polyarthritis. As no definitive diagnostic tools exist, AOSD is diagnosed by extensively excluding a wide range of diseases with similar clinical presentation. To facilitate this process, several sets of diagnostic criteria have been developed. Among them, the Yamaguchi criteria [2] are regarded as the most sensitive, and are, thus, widely used [3]. The Yamaguchi criteria comprise 4 major criteria (fever $\geqq 39^{\circ}$ lasting $\geqq 1$ week; arthralgia or arthritis lasting $\geqq 2$ weeks; typical nonpruritic salmon-colored rash; and leukocytosis $\geqq 10,000 / \mathrm{mm}$, with granulocytes $\geqq 80 \%$ ) and 4 minor criteria (sore throat; lymphadenopathy; splenomegaly; abnormal liver function tests; and negative tests for antinuclear antibody and rheumatoid factor) [2]. The Yamaguchi criteria require the exclusion of other diseases, including infectious diseases, such as viruses and rickettsia; malignant tumors, such as malignant lymphoma; and collagen diseases, such as systemic vasculitis. AOSD is diagnosed if $\geqq 5$ criteria are present, with $\geqq 2$ being major criteria, and no exclusion criteria are present. Despite its wide use, the Yamaguchi criteria are limited to 
the clinical manifestations of this disease and do not reflect the disease mechanism of AOSD.

AOSD can cause macrophage activation syndrome (MAS), a life-threatening complication with a mortality rate as high as 50\% [4]. MAS is a secondary form of hemophagocytic lymphohistiocytosis (HLH), characterized by excessive inflammatory cytokine production (i.e., a cytokine storm), and, consequently, leading to multiple organ failure. Herein, AOSD was diagnosed and treated in a timely manner by the profiling of inflammatory cytokines. Thereby, the progression toward fulminant MAS was prevented.

\section{Case presentation}

The patient was a 21-year-old woman with no medical history. She presented with a maculopapular rash appearing on her trunk and limbs, with an itching sensation, that had lasted for 2 months and was ineffectively treated by a topical antihistamine. She also had a recurring fever for 1 month. Her preceding treatment with prednisolone (PSL; $40 \mathrm{mg}$ ) for 3 days partly resolved her rash, but it reappeared. Additionally, the treatment did not affect her fever of nearly $40{ }^{\circ} \mathrm{C}$. The patient started to develop mild swelling in her bilateral 1st and 2nd metacarpophalangeal joints, as well as in her hand and knee joints, 1 week before being admitted to our hospital.

On physical examination at admission, her blood pressure was $127 / 73 \mathrm{mmHg}$ and pulse rate was 73 beats/min. She was slightly febrile, with a body temperature of $37.0{ }^{\circ} \mathrm{C}$, and her respiration rate was 12 breaths/min with a peripheral capillary oxygen saturation $\left(\mathrm{SpO}_{2}\right)$ level of $96 \%$ (room air). Her body temperature over the next several days was $37-39{ }^{\circ} \mathrm{C}$, fluctuating irregularly, with no periodicity. Lymphadenopathy was found on both sides of her cervix, and hepatosplenomegaly was observed. While no joints were swollen, maculopapular erythemas were found on her trunk and limbs. The salmon-colored rash became exacerbated several times, becoming polymorphic along the course of hospitalization. In the initial blood workup, she had a white blood cell (WBC) count of $3540 / \mu \mathrm{L}$ with $80.5 \%$ neutrophils, hemoglobin of $10.0 \mathrm{~g} / \mathrm{dL}$, platelet count of $13.7 \times 10^{3} / \mu \mathrm{L}$, C-reactive protein (CRP) of $1.10 \mathrm{mg} / \mathrm{L}$, erythrocyte sedimentation rate (ESR) at $60 \mathrm{~min}$ of $61 \mathrm{~mm}, \mathrm{ESR}$ at $120 \mathrm{~min}$ of $88 \mathrm{~mm}$, aspartate aminotransferase (AST) of $157 \mathrm{U} / \mathrm{L}$, alanine aminotransferase (ALT) of $96 \mathrm{U} / \mathrm{L}$, lactate dehydrogenase (LDH) of $920 \mathrm{U} / \mathrm{L}$, ferritin of $1299 \mathrm{ng} / \mathrm{ml}$, fibrinogen of $357 \mathrm{mg} / \mathrm{dL}$, and triglycerides of $100 \mathrm{mg} / \mathrm{dL}$ (Table 1). Abdominal computed tomography revealed splenomegaly (major axis, $10 \mathrm{~cm}$; spleen index, 46.5). The results of all serological tests, conducted to distinguish AOSD from other diseases mimicking AOSD, were negative (Table 2).
In terms of the Yamaguchi criteria [2], the patient met one major and four minor criteria (major criterion: fever over $39^{\circ} \mathrm{C}$ lasting for more than 1 week; minor criteria: lymphadenopathy, splenomegaly, abnormal liver function tests, and negative antinuclear antibody and rheumatoid factor tests), thus falling short of a diagnosis of AOSD. As her arthritis had lasted for less than 2 weeks and her maculopapular erythemas differed from a typical nonpruritic palpable salmoncolored rash, in that they itched and were non-palpable, she did not meet a second major criterion. Nonetheless, as her clinical profile best fit that of AOSD and other disorders had been excluded, we chose to analyze her inflammatory cytokine profile (Fig. 1). Her interleukin (IL)-18 level was greatly increased $(166,000 \mathrm{pg} / \mathrm{ml})$, which is unique to AOSD [5]. This level of increase in serum IL-18 is equivalent to that found in AOSD complicated with MAS. Furthermore, her measured soluble tumor necrosis factor receptor (sTNF) II level and sTNF-RII/RI ratio were also extremely high (sTNF II, 17,000 pg/ml; sTNF-RII/RI, 6.56), which we have reported as characteristic signatures of AOSD or s-JIA with MAS [6].

After admission, she was initially prescribed only acetaminophen, but her fever and arthralgia spontaneously remitted; only a mild skin eruption remained. Her WBC count and CRP normalized, and her liver function also improved. With a tentative diagnosis of AOSD as described above, the administration of PSL $25 \mathrm{mg} /$ day $(0.5 \mathrm{mg} / \mathrm{kg} /$ day $)$ was initiated on the 14th day of hospitalization. PSL was reduced to $20 \mathrm{mg} /$ day at discharge on the 25th day of hospitalization. Although she was asymptomatic and a blood workup (e.g. WBC count, CRP, liver function, ferritin) supported remission for the first several weeks, she then started to complain of mild joint pain. As her serum IL-18 level was still high (Fig. 1), we increased the daily dose of PSL back to $25 \mathrm{mg}$.

Forty days after the initiation of PSL treatment, she relapsed with a typical salmon-colored maculopapular rash and a fever of $39^{\circ} \mathrm{C}$. A blood workup revealed a WBC count of $8650 / \mu \mathrm{L}, \mathrm{CRP}$ of $1.23 \mathrm{mg} / \mathrm{L}$, platelet count of $9.0 \times 10^{3} /$ $\mu \mathrm{L}, \mathrm{AST}$ of $131 \mathrm{U} / \mathrm{L}, \mathrm{ALT}$ of $70 \mathrm{U} / \mathrm{L}, \mathrm{LDH}$ of $755 \mathrm{U} / \mathrm{L}, \mathrm{ESR}$ at $60 \mathrm{~min}$ of $22 \mathrm{~mm}$, ESR at $120 \mathrm{~min}$ of $45 \mathrm{~mm}$, ferritin of $2207 \mathrm{ng} / \mathrm{ml}$, fibrinogen of $180 \mathrm{mg} / \mathrm{dL}$, and triglycerides of $130 \mathrm{mg} / \mathrm{dL}$, thus fulfilling the criteria for MAS. A febrile patient with known or suspected s-JIA is classified as having MAS if ferritin $>684 \mathrm{ng} / \mathrm{ml}$ and any two of following additional four criteria are met: platelet count $\leq 18.1 \times 10^{3} / \mu \mathrm{L}$; aspartate aminotransferase $>48 \mathrm{U} / \mathrm{L}$; triglycerides $>156 \mathrm{mg} /$ $\mathrm{dL}$; and fibrinogen $\leq 360 \mathrm{mg} / \mathrm{dL}$ [7].

The progression of laboratory data is presented in Table 3 . She was readmitted and immediately subjected to a pulse therapy of methylprednisolone $(1 \mathrm{~g})$ administered at 24-h intervals for 3 days, followed by daily administration of $50 \mathrm{mg}$ PSL. Her cytokine profile at the time of relapse (Fig. 1) showed a sharp upregulation in serum IL-18 and neopterin levels. Her sTNF II 
Table 1 Laboratory data during the duration of the first admission

\begin{tabular}{|c|c|c|c|c|c|c|}
\hline Parameter & At the first visit & $\begin{array}{l}\text { At admission } \\
\text { ( } 4 \text { days after the } \\
\text { first visit) }\end{array}$ & $\begin{array}{l}5 \text { days after admis- } \\
\text { sion }\end{array}$ & $\begin{array}{l}1 \text { week after admis- } \\
\text { sion }\end{array}$ & $\begin{array}{l}\text { Before PSL } \\
\text { ( } 3 \text { weeks after the } \\
\text { first visit) }\end{array}$ & Standard value \\
\hline $\begin{array}{l}\text { White blood cell } \\
\text { count }\end{array}$ & $3540 / \mu \mathrm{L}$ & $3600 / \mu \mathrm{L}$ & $3360 / \mu \mathrm{L}$ & $4860 / \mu \mathrm{L}$ & $6650 / \mu \mathrm{L}$ & $4500-7500 / \mu \mathrm{L}$ \\
\hline Neutrophils & $80.5 \%$ & $73.4 \%$ & $67.0 \%$ & $74.3 \%$ & $75.3 \%$ & $42-72 \%$ \\
\hline Hemoglobin & $10.0 \mathrm{~g} / \mathrm{dL}$ & $9.5 \mathrm{~g} / \mathrm{dL}$ & $9.7 \mathrm{~g} / \mathrm{dL}$ & $9.7 \mathrm{~g} / \mathrm{dL}$ & $10.2 \mathrm{~g} / \mathrm{dL}$ & $11.3-15.2 \mathrm{~g} / \mathrm{dL}$ \\
\hline Hematocrit & $31.3 \%$ & $30.3 \%$ & $30.9 \%$ & $30.7 \%$ & $31.3 \%$ & $36-45 \%$ \\
\hline Platelet count & $13.7 \times 10^{3} / \mu \mathrm{L}$ & $15.1 \times 10^{3} / \mu \mathrm{L}$ & $16.5 \times 10^{3} / \mu \mathrm{L}$ & $18.2 \times 10^{3} / \mu \mathrm{L}$ & $15.8 \times 10^{3} / \mu \mathrm{L}$ & $13-35 \times 10^{3} / \mu \mathrm{L}$ \\
\hline $\begin{array}{l}\text { International nor- } \\
\text { malized ratio }\end{array}$ & 1.05 & & & & 1.03 & $0.80-1.20$ \\
\hline $\begin{array}{l}\text { Activated partial } \\
\text { thromboplastin } \\
\text { time }\end{array}$ & $30.5 \mathrm{~s}$ & & & & $28.6 \mathrm{~s}$ & $26.9-38.1 \mathrm{~s}$ \\
\hline Fibrinogen & & & & & $410 \mathrm{mg} / \mathrm{dL}$ & $200-400 \mathrm{mg} / \mathrm{dL}$ \\
\hline C-reactive protein & $1.10 \mathrm{mg} / \mathrm{L}$ & $0.95 \mathrm{mg} / \mathrm{L}$ & $1.02 \mathrm{mg} / \mathrm{L}$ & $1.01 \mathrm{mg} / \mathrm{L}$ & $0.35 \mathrm{mg} / \mathrm{L}$ & $\leq 1.0 \mathrm{mg} / \mathrm{L}$ \\
\hline $\begin{array}{l}\text { Erythrocyte sedi- } \\
\text { mentation rate }\end{array}$ & $61 \mathrm{~mm} / 60 \mathrm{~min}$ & & & & $75 \mathrm{~mm} / 60 \mathrm{~min}$ & \\
\hline $\begin{array}{l}\text { Erythrocyte sedi- } \\
\text { mentation rate }\end{array}$ & $88 \mathrm{~mm} / 120 \mathrm{~min}$ & & & & $101 \mathrm{~mm} / 120 \mathrm{~min}$ & \\
\hline Total protein & $7.5 \mathrm{~g} / \mathrm{dL}$ & $7.0 \mathrm{~g} / \mathrm{dL}$ & $6.9 \mathrm{~g} / \mathrm{dL}$ & $7.3 \mathrm{~g} / \mathrm{dL}$ & $7.6 \mathrm{~g} / \mathrm{dL}$ & $6.9-8.4 \mathrm{~g} / \mathrm{dL}$ \\
\hline Albumin & $3.6 \mathrm{~g} / \mathrm{dL}$ & $3.4 \mathrm{~g} / \mathrm{dL}$ & $3.3 \mathrm{~g} / \mathrm{dL}$ & $3.5 \mathrm{~g} / \mathrm{dL}$ & $3.7 \mathrm{~g} / \mathrm{dL}$ & $3.9-5.1 \mathrm{~g} / \mathrm{dL}$ \\
\hline Triglycerides & & $100 \mathrm{mg} / \mathrm{dL}$ & & & $119 \mathrm{mg} / \mathrm{dL}$ & $30-149 \mathrm{mg} / \mathrm{dL}$ \\
\hline Total bilirubin & $0.5 \mathrm{mg} / \mathrm{dL}$ & $0.5 \mathrm{mg} / \mathrm{dL}$ & & $0.5 \mathrm{mg} / \mathrm{dL}$ & $0.4 \mathrm{mg} / \mathrm{dL}$ & $0.2-1.2 \mathrm{mg} / \mathrm{dL}$ \\
\hline $\begin{array}{l}\text { Aspartate ami- } \\
\text { notransferase }\end{array}$ & $157 \mathrm{U} / \mathrm{L}$ & $113 \mathrm{U} / \mathrm{L}$ & $89 \mathrm{U} / \mathrm{L}$ & $59 \mathrm{U} / \mathrm{L}$ & $41 \mathrm{U} / \mathrm{L}$ & $11-30 \mathrm{U} / \mathrm{L}$ \\
\hline $\begin{array}{l}\text { Alanine ami- } \\
\text { notransferase }\end{array}$ & $96 \mathrm{U} / \mathrm{L}$ & $87 \mathrm{U} / \mathrm{L}$ & $75 \mathrm{U} / \mathrm{L}$ & $52 \mathrm{U} / \mathrm{L}$ & $32 \mathrm{U} / \mathrm{L}$ & 4-30 U/L \\
\hline $\begin{array}{l}\text { Lactate dehydro- } \\
\text { genase }\end{array}$ & $920 \mathrm{U} / \mathrm{L}$ & $802 \mathrm{U} / \mathrm{L}$ & $663 \mathrm{U} / \mathrm{L}$ & $587 \mathrm{U} / \mathrm{L}$ & $488 \mathrm{U} / \mathrm{L}$ & 109-216 U/L \\
\hline $\begin{array}{l}\text { Creatine phospho- } \\
\text { kinase }\end{array}$ & $75 \mathrm{U} / \mathrm{L}$ & $57 \mathrm{U} / \mathrm{L}$ & & & & $40-150 \mathrm{U} / \mathrm{L}$ \\
\hline Blood urea nitrogen & $6.7 \mathrm{mg} / \mathrm{dL}$ & $5.9 \mathrm{mg} / \mathrm{dL}$ & $6.9 \mathrm{mg} / \mathrm{dL}$ & & $11.0 \mathrm{mg} / \mathrm{dL}$ & $8-20 \mathrm{mg} / \mathrm{dL}$ \\
\hline Creatinine & $0.62 \mathrm{mg} / \mathrm{dL}$ & $0.69 \mathrm{mg} / \mathrm{dL}$ & $0.66 \mathrm{mg} / \mathrm{dL}$ & & $0.60 \mathrm{mg} / \mathrm{dL}$ & $0.63-1.03 \mathrm{mg} / \mathrm{dL}$ \\
\hline Sodium & $134 \mathrm{mEq} / \mathrm{L}$ & $138 \mathrm{mEq} / \mathrm{L}$ & & & $140 \mathrm{mEq} / \mathrm{L}$ & $136-148$ mEq/L \\
\hline Potassium & $3.9 \mathrm{mEq} / \mathrm{L}$ & $4.0 \mathrm{mEq} / \mathrm{L}$ & & & $4.0 \mathrm{mEq} / \mathrm{L}$ & $3.6-5.0 \mathrm{mEq} / \mathrm{L}$ \\
\hline Chloride & $98 \mathrm{mEq} / \mathrm{L}$ & $104 \mathrm{mEq} / \mathrm{L}$ & & & $103 \mathrm{mEq} / \mathrm{L}$ & 98-108 mEq/L \\
\hline Glucose & $91 \mathrm{mg} / \mathrm{dL}$ & $78 \mathrm{mg} / \mathrm{dL}$ & & & $76 \mathrm{mg} / \mathrm{dL}$ & $70-109 \mathrm{mg} / \mathrm{dL}$ \\
\hline Ferritin & $1299 \mathrm{ng} / \mathrm{mL}$ & & & $477 \mathrm{ng} / \mathrm{mL}$ & $130 \mathrm{ng} / \mathrm{mL}$ & $12-60 \mathrm{ng} / \mathrm{mL}$ \\
\hline
\end{tabular}

PSL prednisolone

level was also elevated, consistent with the diagnosis of MAS. Our timely intervention with steroid pulse therapy eased the exacerbation of AOSD, and her MAS subsided. After stabilization, she was transferred to another hospital for immunosuppression therapy.

\section{Search strategy}

We searched MEDLINE and the Web of Science for cases of AOSD using cytokine profiling in clinical practice. The 
Table 2 Laboratory data for hepatitis and causative infectious agents

\begin{tabular}{lll}
\hline Parameter & Recorded value & Standard value \\
\hline T-SPOT & Negative & Negative \\
Antinuclear antibody & $<40$ & $<40$ \\
HHV-6 IgM & $<10$ & $<10$ \\
HHV-6 IgG & $\times 60$ & $<10$ \\
CMV-C7HRP & Negative & Negative \\
EBVCA-IgM & 0.9 & $0-0.4$ \\
EBVCA-IgG & 2.3 & $0-0.4$ \\
EBNA-IgG & 3.7 & $0-0.4$ \\
PVB19-IgM & Negative & Negative \\
RF & 4 U/mL & $0-15 \mathrm{U} / \mathrm{mL}$ \\
Anti-CCP antibody & Negative & Negative \\
MMP3 & $106.7 \mathrm{ng} / \mathrm{mL}$ & $16.1-56.8 \mathrm{ng} / \mathrm{mL}$ \\
MPO-ANCA & Negative & Negative \\
PR3-ANCA & Negative & Negative \\
IL-2 receptor & $1843 \mathrm{U} / \mathrm{mL}$ & $135-483 \mathrm{U} / \mathrm{mL}$ \\
\hline
\end{tabular}

$A N C A$ antineutrophil cytoplasmic antibodies, $C C P$ cyclic citrullinated peptide, $C M V$ cytomegalovirus, EBNA Epstein-Barr nuclear antigen, EBVCA Epstein-Barr virus capsid antigen, HHV-6 Human Herpesvirus 6, Ig immunoglobulin, $I L$ interleukin, $M M P 3$ matrix metallopeptidase 3, $M P O$ myeloperoxidase, $P R 3$ proteinase $3, P V B 19$ parvovirus B $19, R F$ rheumatoid factor

search terms of this first search were "adult-onset Still's disease" and "cytokine profile", with no time limits. We also searched for "adult-onset Still's disease" and "predictor", with no time limits. We reviewed the abstracts of the relevant studies and retrieved the appropriate articles. We also scrutinized the reference lists of the included studies to identify additional references.

Two authors independently scanned the titles and abstracts for the following inclusion criteria: (1) cases of AOSD involving the use of cytokine profiling in clinical practice or the predictors of AOSD with MAS; (2) published in English, and (3) published in a peer-reviewed journal. Reviews and other study types lacking clinical data from individual patients were excluded. There was no disagreement between the two reviewers at any point in the selection process.

The first search produced 13 hits, of which 5 were research papers related to the diagnosis of AOSD using cytokine profiling. The second search produced 15 hits, of which only one was a research paper related to the predictors of AOSD with MAS.

\section{Discussion}

We presented a case in which cytokine profiling was useful for the diagnosis of AOSD, despite the patient not fulfilling the Yamaguchi criteria, and the prediction of MAS.
As the etiology of AOSD remains largely unknown, its diagnosis is based on scoring each suspected case by its clinical appearance using a set of criteria, such as those proposed by Yamaguchi et al. [2] and others. Therefore, the Yamaguchi criteria do not reflect the disease mechanism of AOSD. Additionally, the rapid laboratory changes were not useful in diagnosing AOSD, but were useful in diagnosing MAS.

Recent extensive investigations have highlighted the altered immune-system status in AOSD and its childhood counterpart, s-JIA [4]. Both disorders are now postulated to be in the same disease entity and are characterized by the indiscriminate activation of antigen-presenting cells, including macrophages, and an elevation in cytotoxic $\mathrm{T}$ cell activities. These cyto-immunological activations accompany the extensive production of a set of inflammatory cytokines. Specifically, the serum levels of IL-1, IL-6, and IL-18 are elevated in both AOSD and s-JIA [8]. Therefore, the direct measurement of cytokines such as IL-6 and IL-18 may contribute to its diagnosis. Suzuki et al. reported that patients with secondary MAS due to s-JIA/AOSD, active or inactive disease states of s-JIA/AOSD (but no MAS), Epstein-Barr virus-induced hemophagocytic lymphohistiocytosis, and Kawasaki disease have distinct cytokine profiles of serum IL-18, IL-6, neopterin, sTNF-RI, and sTNF-RII [8]. While IL-18 is elevated in other diseases such as systemic lupus erythematosus, the IL-18 level reaches a height of $10^{3} \mathrm{pg} / \mathrm{ml}$ in these diseases. In contrast, s-JIA/AOSD is characterized by a marked rise in IL-18 to over $10^{4} \mathrm{pg} / \mathrm{ml}$. [9].

Our literature search revealed 5 research papers related to the diagnosis of AOSD. IL-18 was reported by Saiki et al. to be markedly elevated in 150 patients with AOSD [10]. In another study, Chen et al. reported significantly higher levels of IL-6, IL-8, IL-18, and TNF-alpha in both sera and pathological tissues of 50 patients with active AOSD than in the tissues of 20 patients with active rheumatoid arthritis or 20 healthy controls [11]. Additionally, Kasama et al. reported that the concentrations of cytokines and chemokines, including IL-18, soluble IL-2 receptor (sIL-2R), and CX3CL1, were significantly higher in patients with untreated, active AOSD than in controls [12]. Inoue et al. reported that 33 patients with AOSD had a significant increase in IL-18 [5], and identified a characteristic cytokine profile pattern based on serum concentrations of IL-18, IL-6, neopterin, sTNF-RI, and sTNF-RII in AOSD [5]. In the present case, our patient exhibited a similar cytokine profile as that determined by Inoue et al. to be characteristic of AOSD. Lastly, Jamilloux et al. recommended the selection of therapeutic agents according to the cytokine levels of IL-1, IL-6, and TNF- $\alpha[13]$.

We and others have found cytokine activation patterns among inflammatory diseases to be very useful for the diagnosis and management of AOSD [4, 8]. Thus, we have 


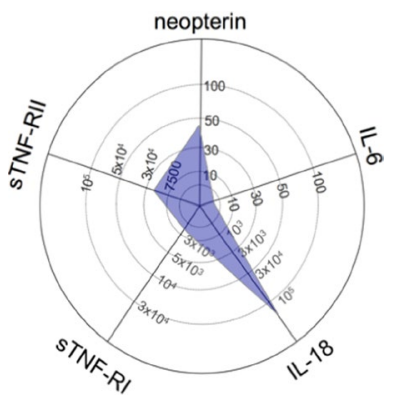

at the first hospitalization

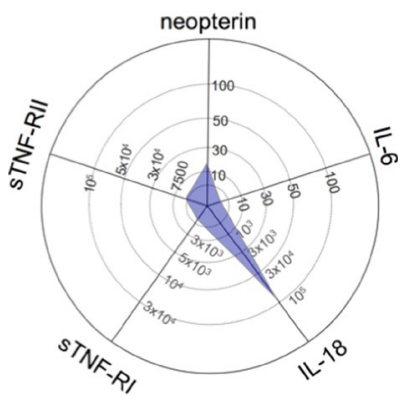

at discharge

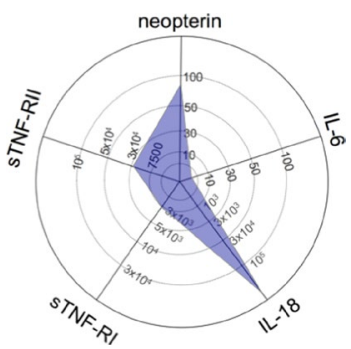

at the second hospitalization

\begin{tabular}{|c|c|c|c|c|}
\hline Parameter & $\begin{array}{l}\text { Recorded value } \\
\text { at the first } \\
\text { hospitalization }\end{array}$ & $\begin{array}{l}\text { Recorded value } \\
\text { at discharge }\end{array}$ & $\begin{array}{l}\text { Recorded value } \\
\text { at the second } \\
\text { hospitalization }\end{array}$ & Standard value \\
\hline Neopterin & $45.0 \mathrm{mmol} / \mathrm{L}$ & $16.0 \mathrm{mmol} / \mathrm{L}$ & $82.3 \mathrm{mmol} / \mathrm{L}$ & $\leq 5 \mathrm{mmol} / \mathrm{L}$ \\
\hline IL-6 & $3 \mathrm{pg} / \mathrm{mL}$ & $4 \mathrm{pg} / \mathrm{mL}$ & $3 \leq \mathrm{pg} / \mathrm{mL}$ & $\leq 5 \mathrm{pg} / \mathrm{mL}$ \\
\hline IL-18 & $166,000 \mathrm{pg} / \mathrm{mL}$ & $63,500 \mathrm{pg} / \mathrm{mL}$ & $415,000 \mathrm{pg} / \mathrm{mL}$ & $\leq 500 \mathrm{pg} / \mathrm{mL}$ \\
\hline sTNF-RI & $2,590 \mathrm{pg} / \mathrm{mL}$ & $1,400 \mathrm{pg} / \mathrm{mL}$ & $3,160 \mathrm{pg} / \mathrm{mL}$ & $484-1,407 \mathrm{pg} / \mathrm{mL}$ \\
\hline sTNF-RII & $17,000 \mathrm{pg} / \mathrm{mL}$ & $5,100 \mathrm{pg} / \mathrm{mL}$ & $28,800 \mathrm{pg} / \mathrm{mL}$ & $829-2,262 \mathrm{pg} / \mathrm{mL}$ \\
\hline sTNF-RII/RI & 6.56 & 3.64 & 9.11 & $<5$ \\
\hline
\end{tabular}

IL, interleukin; sTNF, soluble tumor necrosis factor

Fig. 1 Cytokine profiling using a laser chart at the first hospitalization, at discharge, and at the second admission. $I L$ interleukin, $s T N F$ soluble tumor necrosis factor

proposed cytokine profiling as a new etiology-oriented diagnostic criterion for AOSD and s-JIA.

Cytokine profiling may also be useful for predicting MAS. Approximately $12-17 \%$ of patients with AOSD develop MAS [14]. As in the present case, AOSD disease will sometimes worsen after initial steroid therapy [15]. The hallmark of MAS is an uncontrolled and dysfunctional immune response involving the continual activation and expansion of T lymphocytes and macrophages, leading to marked hypercytokinemia [16]. In our previous study, we found that serum levels of IL-18 and sTNF-RII, as well as the sTNF-RII/RI ratio, correlate well with the active/ inactive states of AOSD and s-JIA, and their complication with MAS. Furthermore, the sTNF-RII/RI ratio as a predictor of MAS shows a sensitivity of $87.5 \%$, the specificity of $92.3 \%$, and likelihood ratio of 10.7 , with a cutoff value of 4.5 [6]. In the present case, the sTNF-RII/RI ratio was 6.56; thus, we predicted MAS during the first admission. In the second admission, her cytokine profile pattern reflected a sharp upregulation in serum IL-18 and neopterin levels. Her sTNF-RII level was also elevated, 
Table 3 Laboratory data during the duration of the second admission

\begin{tabular}{|c|c|c|c|c|}
\hline Parameter & $\begin{array}{l}\text { PSL ( } 6 \text { weeks after the } \\
\text { first admission) }\end{array}$ & $\begin{array}{l}\text { At the second admission } \\
\text { ( } 2 \text { months after the first admis- } \\
\text { sion) }\end{array}$ & $\begin{array}{l}\text { One day after the } \\
\text { second admission }\end{array}$ & Standard value \\
\hline White blood cell count & $9950 / \mu \mathrm{L}$ & $8650 / \mu \mathrm{L}$ & $4510 / \mu \mathrm{L}$ & $4500-7500 / \mu \mathrm{L}$ \\
\hline Neutrophils & $92.4 \%$ & $94.2 \%$ & $84.7 \%$ & $42-72 \%$ \\
\hline Hemoglobin & $10.4 \mathrm{~g} / \mathrm{dL}$ & $10.7 \mathrm{~g} / \mathrm{dL}$ & $10.3 \mathrm{~g} / \mathrm{dL}$ & $11.3-15.2 \mathrm{~g} / \mathrm{dL}$ \\
\hline Hematocrit & $33.1 \%$ & $33.0 \%$ & $31.8 \%$ & $36-45 \%$ \\
\hline Platelet count & $17.0 \times 10^{3} / \mu \mathrm{L}$ & $9.0 \times 10^{3} / \mu \mathrm{L}$ & $6.5 \times 10^{3} / \mu \mathrm{L}$ & $13-35 \times 10^{3} / \mu \mathrm{L}$ \\
\hline International normalized ratio & 0.92 & 1.14 & 1.14 & $0.80-1.20$ \\
\hline Activated partial thromboplastin time & $27.2 \mathrm{~s}$ & $33.1 \mathrm{~s}$ & $31.5 \mathrm{~s}$ & $26.9-38.1 \mathrm{~s}$ \\
\hline Fibrinogen & $262 \mathrm{mg} / \mathrm{dL}$ & $180 \mathrm{mg} / \mathrm{dL}$ & $151 \mathrm{mg} / \mathrm{dL}$ & $200-400 \mathrm{mg} / \mathrm{dL}$ \\
\hline C-reactive protein & $0.09 \mathrm{mg} / \mathrm{L}$ & $1.23 \mathrm{mg} / \mathrm{L}$ & $1.57 \mathrm{mg} / \mathrm{L}$ & $\leq 1.0 \mathrm{mg} / \mathrm{L}$ \\
\hline Erythrocyte sedimentation rate & $25 \mathrm{~mm} / 60 \mathrm{~min}$ & & $22 \mathrm{~mm} / 60 \mathrm{~min}$ & \\
\hline Erythrocyte sedimentation rate & $53 \mathrm{~mm} / 120 \mathrm{~min}$ & & $45 \mathrm{~mm} / 120 \mathrm{~min}$ & \\
\hline Total protein & $7.9 \mathrm{~g} / \mathrm{dL}$ & $7.7 \mathrm{~g} / \mathrm{dL}$ & $6.9 \mathrm{~g} / \mathrm{dL}$ & $6.9-8.4 \mathrm{~g} / \mathrm{dL}$ \\
\hline Albumin & $4.6 \mathrm{~g} / \mathrm{dL}$ & $4.2 \mathrm{~g} / \mathrm{dL}$ & $3.8 \mathrm{~g} / \mathrm{dL}$ & $3.9-5.1 \mathrm{~g} / \mathrm{dL}$ \\
\hline Triglycerides & $86 \mathrm{mg} / \mathrm{dL}$ & $130 \mathrm{mg} / \mathrm{dL}$ & $164 \mathrm{mg} / \mathrm{dL}$ & $30-149 \mathrm{mg} / \mathrm{dL}$ \\
\hline Total bilirubin & $0.5 \mathrm{mg} / \mathrm{dL}$ & $0.5 \mathrm{mg} / \mathrm{dL}$ & $0.5 \mathrm{mg} / \mathrm{dL}$ & $0.2-1.2 \mathrm{mg} / \mathrm{dL}$ \\
\hline Aspartate aminotransferase & $29 \mathrm{U} / \mathrm{L}$ & $131 \mathrm{U} / \mathrm{L}$ & $222 \mathrm{U} / \mathrm{L}$ & $11-30 \mathrm{U} / \mathrm{L}$ \\
\hline Alanine aminotransferase & $19 \mathrm{U} / \mathrm{L}$ & $70 \mathrm{U} / \mathrm{L}$ & $131 \mathrm{U} / \mathrm{L}$ & 4-30 U/L \\
\hline Lactate dehydrogenase & $341 \mathrm{U} / \mathrm{L}$ & $755 \mathrm{U} / \mathrm{L}$ & $989 \mathrm{U} / \mathrm{L}$ & $109-216 \mathrm{U} / \mathrm{L}$ \\
\hline Creatine phosphokinase & $24 \mathrm{U} / \mathrm{L}$ & $29 \mathrm{U} / \mathrm{L}$ & & $40-150 \mathrm{U} / \mathrm{L}$ \\
\hline Blood urea nitrogen & $10.0 \mathrm{mg} / \mathrm{dL}$ & $7.3 \mathrm{mg} / \mathrm{dL}$ & $10.4 \mathrm{mg} / \mathrm{dL}$ & $8-20 \mathrm{mg} / \mathrm{dL}$ \\
\hline Creatinine & $0.59 \mathrm{mg} / \mathrm{dL}$ & $0.81 \mathrm{mg} / \mathrm{dL}$ & $0.81 \mathrm{mg} / \mathrm{dL}$ & $0.63-1.03 \mathrm{mg} / \mathrm{dL}$ \\
\hline Sodium & $139 \mathrm{mEq} / \mathrm{L}$ & $132 \mathrm{mEq} / \mathrm{L}$ & $134 \mathrm{mEq} / \mathrm{L}$ & $136-148 \mathrm{mEq} / \mathrm{L}$ \\
\hline Potassium & $4.3 \mathrm{mEq} / \mathrm{L}$ & $4.0 \mathrm{mEq} / \mathrm{L}$ & $3.9 \mathrm{mEq} / \mathrm{L}$ & $3.6-5.0 \mathrm{mEq} / \mathrm{L}$ \\
\hline Chloride & $103 \mathrm{mEq} / \mathrm{L}$ & $97 \mathrm{mEq} / \mathrm{L}$ & $97 \mathrm{mEq} / \mathrm{L}$ & 98-108 mEq/L \\
\hline Glucose & $106 \mathrm{mg} / \mathrm{dL}$ & $135 \mathrm{mg} / \mathrm{dL}$ & $106 \mathrm{mg} / \mathrm{dL}$ & $70-109 \mathrm{mg} / \mathrm{dL}$ \\
\hline Ferritin & $28 \mathrm{ng} / \mathrm{mL}$ & $2207 \mathrm{ng} / \mathrm{mL}$ & & $12-60 \mathrm{ng} / \mathrm{mL}$ \\
\hline
\end{tabular}

$P S L$ prednisolone

consistent with the diagnosis of MAS. We were able intervene timely with steroid pulse therapy.

Our literature search also revealed 1 research paper related to the predictors of AOSD with MAS. In addition, one other research paper was related to the remission of AOSD. Seo et al. report that the neutrophil-to-lymphocyte (NLR) ratio is a useful marker for predicting the onset of MAS in AOSD [17]. The NLR, with a cutoff value of 5.86, showed a sensitivity of $89.4 \%$, specificity of $87.8 \%$, and area under the curve of 0.794 . However, while the NLR is a simple and easy tool, it is difficult to use clinically because it rises easily, even in bacterial infections. In contrast, Jung et al. reported that an elevated IL-18 level is a better predictor of recurrence after AOSD treatment than are the ESR, CRP, and ferritin levels, which may indicate the activity of AOSD in patients [18].

We suggest that the current case further proves the usefulness of cytokine profiling for the diagnosis of AOSD, and for predicting the development of the malicious complication of MAS. In the present case, the sTNF-RII level and sTNF-RII/RI ratio remained elevated, despite the spontaneous tendency of the physical and general blood test findings, reflecting a profile predictive of MAS. Thus, we started steroid therapy as MAS developed. As her cytokine profile predicted MAS at the diagnosis of AOSD, we were able to promptly start an intervention to mitigate the future risk for MAS.

In conclusion, the present case supports the usefulness of cytokine profiling for the diagnosis of AOSD and the prediction of MAS. Conventionally, the diagnosis of AOSD is not specific. However, it is anticipated that cytokine IL-18 elevation is involved in the pathology; thus, cytokine IL-18 elevation is expected to contribute to the diagnosis of AOSD in the future. In regards to treatment, while steroids are useful, new therapeutic drugs for cytokines have also emerged [11]. Thus, we suggest that cytokine profiling may be useful for the diagnosis and management of AOSD. Only cytokine profiling, not 
the rapid changes in laboratory test results, helped in this specific case.

Abbreviations: AOSD, Adult-onset Still's disease; HLH, hemophagocytic lymphohistiocytosis; IL, interleukin; MAS, macrophage activation syndrome; PSL, prednisolone; s-JIA, systemic juvenile idiopathic arthritis; sTNF, soluble tumor necrosis factor receptor.

Acknowledgments We would like to thank Editage (www.editage.com) for English language editing.

Author contributions KG and MS managed the case, and prepared and revised the manuscript. TK assisted with the preparation and revision of the manuscript. AY assisted with data analysis and revision of the manuscript. HA assisted with manuscript revision and prepared the figures. All co-authors approved the final manuscript as submitted and agree to be accountable for all aspects of the work. All co-authors take full responsibility for the integrity of the study and the final manuscript.

\section{Compliance with ethical standards}

Conflict of interest The authors declare that they have no competing interests.

Informed consent Written informed consent was obtained from the patient for the publication of this case report and accompanying images. A copy of the written consent is available for review by the Editor of this journal.

Open Access This article is distributed under the terms of the Creative Commons Attribution 4.0 International License (http://creativeco mmons.org/licenses/by/4.0/), which permits unrestricted use, distribution, and reproduction in any medium, provided you give appropriate credit to the original author(s) and the source, provide a link to the Creative Commons license, and indicate if changes were made.

\section{References}

1. Bagnari V, Colina M, Ciancio G, Govoni M, Trotta F (2010) Adult-onset Still's disease. Rheumatol Int 30:855-862. https:// doi.org/10.1007/s00296-009-1291-y

2. Yamaguchi M, Ohta A, Tsunematsu T, Kasukawa R, Mizushima Y, Kashiwagi H, Kashiwazaki S, Tanimoto K, Matsumoto Y, Ota T (1992) Preliminary criteria for classification of adult Still's disease. J Rheumatol 19:424-430

3. Masson C, Le Loet X, Liote F, Dubost JJ, Boissier MC, PerrouxGoumy L, Bregeon C, Audran M (1996) Comparative study of 6 types of criteria in adult Still's disease. J Rheumatol 23:495-497

4. Li X, Qu B, Nie Y, Zhu G, Li W, Mu F (2014) Clinical features of macrophage activation syndrome in the adult northern Chinese population. Lupus 23:785-792. https://doi.org/10.1177/09612 03314529467

5. Inoue N, Shimizu M, Tsunoda S, Kawano M, Matsumura M, Yachie A (2016) Cytokine profile in adult-onset Still's disease: comparison with systemic juvenile idiopathic arthritis. Clin Immunol 169:8-13. https://doi.org/10.1016/j.clim.2016.05.010

6. Shimizu M, Inoue N, Mizuta M, Nakagishi Y, Yachie A (2018) Characteristic elevation of soluble TNF receptor II: i ratio in macrophage activation syndrome with systemic juvenile idiopathic arthritis. Clin Exp Immunol 191:349-355. https://doi.org/10.1111/ cei. 13026

7. Ravelli A, Minoia F, Davì S, Horne A, Bovis F, Pistorio A, Aricò M, Avcin T, Behrens EM, De Benedetti F, Filipovic L, Grom AA, Henter JI, Ilowite NT, Jordan MB, Khubchandani R, Kitoh T, Lehmberg K, Lovell DJ, Miettunen P, Nichols KE, Ozen S, Pachlopnik Schmid J, Ramanan AV, Russo R, Schneider R, Sterba G, Uziel Y, Wallace C, Wouters C, Wulffraat N, Demirkaya E, Brunner HI, Martini A, Ruperto N, Cron RQ, Paediatric Rheumatology International Trials Organisation; Childhood Arthritis and Rheumatology Research Alliance; Pediatric Rheumatology Collaborative Study Group; Histiocyte Society (2016) 2016 Classification Criteria for Macrophage Activation Syndrome complicating Systemic Juvenile Idiopathic Arthritis: A European League Against Rheumatism/American College of Rheumatology/Paediatric Rheumatology International Trials Organisation collaborative initiative. Ann Rheum Dis 75:481-489. https://doi. org/10.1002/art.39332

8. Shimizu M, Yokoyama T, Yamada K, Kaneda H, Wada H, Wada T, Toma T, Ohta K, Kasahara Y, Yachie A (2010) Distinct cytokine profiles of systemic-onset juvenile idiopathic arthritis-associated macrophage activation syndrome with particular emphasis on the role of interleukin-18 in its pathogenesis. Rheumatology (Oxford) 49:1645-1653. https://doi.org/10.1093/rheumatology/keg133

9. Wu CY, Yang HY, Yao TC, Liu SH, Huang JL (2016) Serum IL-18 as biomarker in predicting long-term renal outcome among pediatric-onset systemic lupus erythematosus patients. Medicine (Baltimore). 95:e5037. https://doi.org/10.1136/lupus-2017-00021 5.334

10. Saiki O, Uda H, Nishimoto N, Miwa T, Mima T, Ogawara T, Azuma N, Katada Y, Sawaki J, Tsutsui H, Matsui K, Maeda A, Nakanishi K (2004) Adult Still's disease reflects a Th2 rather than a Th1 cytokine profile. Clin Immunol 112:120-125. https://doi. org/10.1016/j.clim.2004.03.023

11. Chen DY, Lan JL, Lin FJ, Hsieh TY (2004) Proinflammatory cytokine profiles in sera and pathological tissues of patients with active untreated adult onset Still's disease. J Rheumatol 31:2189-2198

12. Kasama T, Furuya H, Yanai R, Ohtsuka K, Takahashi R, Yajima N, Miwa Y, Kobayashi K (2012) Correlation of serum CX3CL1 level with disease activity in adult-onset Still's disease and significant involvement in hemophagocytic syndrome. Clin Rheumatol 31:853-860. https://doi.org/10.1007/s10067-012-1952-1

13. Jamilloux Y, Gerfaud-Valentin M, Henry T, Sève P (2014) Treatment of adult-onset Still's disease: a review. Ther Clin Risk Manag 11:33-43. https://doi.org/10.2147/TCRM.S64951

14. Jamilloux Y, Gerfaud-Valentin M, Martinon F, Belot A, Henry T, Sève P (2015) Pathogenesis of adult-onset Still's disease: new insights from the juvenile counterpart. Immunol Res 61:53-62. https://doi.org/10.1007/s12026-014-8561-9

15. de Boysson H, Fevrier J, Nicolle A, Auzary C, Geffray L (2013) Tocilizumab in the treatment of the adult-onset Still's disease: current clinical evidence. Clin Rheumatol 32:141-147. https:// doi.org/10.1007/s 10067-2105-2

16. Ravelli A (2002) Macrophage activation syndrome. Curr Opin Rheumatol 14:548-552

17. Seo JY, Suh CH, Jung JY, Kim AR, Yang JW, Kim HA (2017) The neutrophil-to-lymphocyte ratio could be a good diagnostic marker and predictor of relapse in patients with adult-onset Still's disease: a STROBE-compliant retrospective observational analysis. Medicine (Baltimore). 96:e7546. https://doi.org/10.1097/MD.00000 00000007546

18. Jung KH, Kim JJ, Lee JS, Park W, Kim TH, Jun JB, Yoo DH (2014) Interleukin-18 as an efficient marker for remission and follow-up in patients with inactive adult-onset Still's disease. 
Scand J Rheumatol 43:162-169. https://doi.org/10.3109/03009 742.2013 .824023

Publisher's Note Springer Nature remains neutral with regard to jurisdictional claims in published maps and institutional affiliations. 